Joanna Sobańska

Uniwersytet Warszawski

joanna.sobanska@uw.edu.pl

\title{
OCENA WŁASNYCH ZDOLNOŚCI UCZNIÓW UZDOLNIONYCH JĘZYKOWO W POLSKICH SZKOŁACH PONADGIMNAZJALNYCH
}

\author{
Assessment of one's skills by linguistically talented students \\ in Polish upper-secondary schools
}

An exceptionally linguistically talented student should have all the predispositions to be multi-linguistic. The reason is that such skills, at least potentially, assume high predispositions to learn all foreign languages. And even though the process of language learning and its efficiency depends on many other factors, one of them is the assessment of one's skills and potential by the linguistically talented student. The aim of the article is to present convictions of students identified as linguistically talented with respect to their skills and achievements concerning foreign language learning. A large part of the paper deals with the presentation of theoretical aspects related to linguistic skills and a short analysis of selected factors that influence the development of linguistic skills in students, in particular the assessment of own skills and possibilities by students (self-assessment).

Keywords: foreign language skills, identification of language talented students, learning achievements in foreign languages, assessment of one's skills

Słowa kluczowe: zdolności do nauki języków obcych, identyfikowanie uczniów uzdolnionych językowo, osiągnięcia w nauce języków obcych, ocena własnych uzdolnień 


\section{Wstęp}

Uczeń szczególnie uzdolniony w nauce języków obcych ma wszelkie predyspozycje do tego, aby być osobą wielojęzyczną. Uzdolnienia takie zakładają bowiem - przynajmniej potencjalnie - wysokie predyspozycje do nauki wszystkich języków obcych. Tymczasem w praktyce edukacyjnej można spotkać jednostki uzdolnione językowo, które mimo swoich ponadprzeciętnych możliwości nie osiągają wysokich wyników w nauce języka obcego. Powodów takiego stanu rzeczy jest wiele, a poznanie ich oraz wiedza na temat samych zdolności i ich uwarunkowań stanowią podstawę wszelkich działań mających na celu właściwe rozpoznanie ucznia uzdolnionego językowo oraz zaplanowanie i realizację działań umożliwiających mu rozwijanie swoich zdolności.

Jednym z czynników mogących mieć wpływ na osiągnięcia szkolne uczniów uzdolnionych językowo jest ocena własnych zdolności. Niedocenianie siebie w tym zakresie może bowiem negatywnie wpłynąć na motywację do nauki języka i zahamować proces uczenia się. Z drugiej strony ocena siebie i własnych możliwości nie jest cechą stałą i podlega wpływowi czynników zewnętrznych, może zatem być kształtowana również w procesie rozwijania uzdolnień językowych na lekcji języka obcego.

Celem niniejszego artykułu jest nie tylko przedstawienie czynników kognitywnych, jakie leżą u podstaw zdolności do nauki języków obcych, ale również osobowościowo-afektywnych oraz zależności między nimi. Centralny punkt rozważań stanowią badania własne, pozwalające ukazać, jak uczniowie zidentyfikowani jako uzdolnieni językowo oceniają własne zdolności.

\section{Pojęcie i struktura zdolności językowych}

Wiedza na temat czynników kognitywnych składających się na tzw. zdolności do nauki języków obcych ${ }^{1}$ ma znaczenie nie tylko ze względu na możliwość prognozowania przyszłych sukcesów w tym zakresie. Wpływa ona także na kształtowanie procesu nauczania uczniów uzdolnionych językowo. Stąd też próba analizy struktury tych czynników zdaje się być uzasadniona.

Zdolności językowe, jak zauważają Sękowski i Bilyakovska (2011: 22), należą do grupy zdolności specjalnych, które z kolei są definiowane jako „Względnie stałe warunki wewnętrzne człowieka determinujące efektywność

\footnotetext{
${ }^{1} \mathrm{~W}$ literaturze przedmiotu określenia zdolności językowe, uzdolnienia językowe czy też predyspozycje do nauki języków obcych są używane synonimicznie dla określenia zdolności do nauki języków obcych (Esser, 1982; Rysiewicz, 2010; Pawlak, 2011; Sękowski i Bilyakovska, 2011; Biedroń, 2012); w niniejszym tekście relacja ta została także zachowana.
} 
wykonywania czynności w specyficznej sferze jego działalności" (Strelau, 1997: 223). W przypadku zdolności językowych ową sferą działalności człowieka jest proces uczenia się języków obcych. Próby podania jasnej definicji tego rodzaju zdolności w zakresie uczenia się języków obcych były podejmowane wielokrotnie. Carroll (1993: 16) opisuje je ogólnie jako uzdolnienia kognitywne, które wykazują wyraźne zależności z wynikami uczenia się języków obcych. Oznacza to, że warunkują one ten proces. Podobnie zdolności językowe definiuje Rysiewicz (2010: 54), według którego jest to pewien potencjał kognitywny kształtujący przyszły poziom umiejętności językowych. Według niego zdolności te są względnie trwałe, niezależne od doświadczenia i jedynie w bardzo niewielkim stopniu dają się modyfikować w toku ćwiczeń.

Z analizy wyników prowadzonych od dziesięcioleci badań nad zdolnościami do nauki języków obcych można wnioskować, że wszystkie koncepcje owych zdolności przedstawiają je nie jako jednolity konstrukt, jedną zdolność, lecz raczej jako sumę komponentów wzajemnie się uzupełniających i mogących występować u uczniów w różnym natężeniu. Ich podstawy stanowią natomiast procesy przetwarzania informacji, które warunkują powodzenie w nauce języka obcego. Takie stanowisko reprezentują zarówno ci badacze, którzy nie uznają zdolności językowych jako osobnego rodzaju zdolności (Morgan, 1953 za: Schütt, 1974; Pimsleur, Stochwell i Comrey, 1962), jak również zwolennicy tezy o zdolnościach językowych jako o odrębnym konstrukcie (Carroll i Sapon, 1959; Sang i Vollmer, 1978; Esser, 1982; Wesche, Edwards i Welss, 1982; Skehan, 1998; Grigorenko, Sternberg i Ehrman, 2000).

W powyższym rozumieniu zdolności nie są jednym czynnikiem, a raczej pewną ich konstelacją. Badania nad istotą i strukturą zdolności językowych pozwoliły zatem wyodrębnić takie czynniki kognitywne jak:

- fonetyczne kodowanie (umiejętność przechowywania materiału językowego przez czas niezbędny do jego audytywnego rozpoznania i późniejszego przywoływania z pamięci);

- wrażliwość gramatyczna (umiejętność rozpoznawania funkcji słów w zdaniu);

- $\quad$ pamięć robocza (zdolność zapamiętywania w krótkim czasie znacznej ilości materiału językowego i skojarzeń);

- indukcyjne przyswajanie języka (umiejętność wnioskowania o formie językowej, regułach i strukturze języka na podstawie przykładów) (Sobańska-Jędrych, 2010: 61).

Jak zauważa Rysiewicz (2010: 52), każda z wyróżnionych pod-zdolności może występować w różnym natężeniu cechy u różnych uczniów. Dzięki takiemu ujęciu proces uczenia się języków obcych prowadzący do wysokich osiągnięć w 
tym zakresie może odbywać się na wiele sposobów, co jest podstawą wypracowania indywidualnych działań wspierających proces uczenia się języków obcych uczniów uzdolnionych językowo.

Nieco inne podejście do struktury zdolności prezentuje Snow (1994 za: Biedroń, 2012: 80-81), według którego zdolności wykraczają poza sferę kognitywną i obejmują w swojej strukturze również pewne uwarunkowania osobowościowo-motywacyjne. Analizując takie ujęcie, należy się zgodzić, że cechy te (osobowościowe i motywacyjne) z pewnością decydują o wysokich wynikach w nauce języków obcych, jednak pojawia się pytanie, czy faktycznie stanowią strukturę zdolności. Jeśli by tak było, wskazywałoby to na ich wrodzony charakter. I o ile taki charakter mają cechy osobowościowe, dające się kształtować pod wpływem czynników zewnętrznych, to motywacja do takich cech nie należy. Podejście prezentowane przez Snowa tworzy podstawę do badań nad związkami osobowości ze zdolnościami językowymi (Biedroń, 2012: 77-91).

\section{Osobowościowo-motywacyjne uwarunkowania zdolności językowych}

Analiza powyższych koncepcji zdolności językowych pozwala zadać pytanie o ich związek z osobowością. Pojawia się zatem pytanie, czy, a jeśli tak, to w jakim zakresie osobowość jest związana ze zdolnościami w nauce języków obcych.

W jednym z najbardziej aktualnych modeli osobowości, tzw. Modelu Wielkiej Piątki (Costa i McCrae, 1992), przyjmuje się, że osobowość daje się w pełni scharakteryzować poprzez pięć głównych cech: otwartości na doświadczenie, sumienności, ekstrawersji, ugodowości oraz neurotyczności. Analiza poszczególnych wymiarów osobowości ucznia w kontekście ich powiązań ze zdolnościami do nauki języków obcych ukazuje ich zróżnicowanie. Wskazują na nie badania Biedroń (2012: 88), z których wynika, że osoby o wysokich zdolnościach językowych charakteryzują się głównie otwartością na doświadczenie oraz sumiennością. Badania te ukazały ponadto dodatnią korelację motywacji ze zdolnościami językowymi. Jednocześnie Biedroń podkreśla, że czynniki osobowościowe wykazują nieliniowy związek ze zdolnościami poznawczymi i decydują o ich realizacji, tj. o sukcesie w nauce języka obcego.

Nieco inne wnioski z badań formułują Sękowski i Rudź (2011: 39-41), wskazując, że choć uczniowie uzdolnieni językowo wykazują w minimalnym zakresie wyższe natężenie pewnych cech osobowości (jak otwartość czy ugodowość), to jednoznacznie należy stwierdzić, że to, co różnicuje uczniów uzdolnionych językowo, to właśnie różne konstelacje cech osobowości. Określenie, że wszyscy uczniowie uzdolnieni językowo są otwarci, ekstrawertyczni, tolerancyjni, posiadają wysoką samoocenę oraz wysoką motywację do nauki języków obcych, byłoby uproszczeniem. Różne wymiary osobowości oraz motywacja 
podlegają wpływom otoczenia, zatem nie są stałe nawet w przypadku poszczególnych uczniów. Analiza owych wymiarów jest jednak istotna z perspektywy poznania ucznia uzdolnionego językowo, podejmowania działań w celu rozwijania jego zdolności, a przede wszystkim dla ukazania nauczycielskich sposobów rozpoznawania tychże uczniów.

Związek motywacji ze zdolnościami to kolejny z kierunków badań nad uwarunkowaniami funkcjonowania szkolnego uczniów zdolnych. Ważność tego czynnika dla rozwoju zdolności jest oczywista. Dzięki niej osoba uzdolniona jest w stanie realizować swoje potencjalne możliwości intelektualne i twórcze. Podobnie jednak, jak nie ma jednego modelu osobowości, który byłby charakterystyczny dla wszystkich uczniów zdolnych, nie można mówić również o tym, że każdy uczeń uzdolniony posiada wysoką motywację do działania. Motywacja bowiem jest determinowana różnorodnymi czynnikami zewnętrznymi, jak środowisko, oraz wewnętrznymi, odnoszącymi się przede wszystkim do samooceny. I choć nieliczne badania dotyczące związku motywacji ze zdolnościami językowymi zdają się go potwierdzać (Biedroń, 2012: 88), ze względu na jej dynamiczny charakter trudno przyjąć ją za stałą cechę uczniów uzdolnionych językowo. Można natomiast uznać, że motywacja ma jedynie znaczenie jako element warunkujący realizację potencjalnych predyspozycji językowych, a przyjęcie jej za ich wskaźnik z góry ogranicza możliwość trafnego zidentyfikowania uczniów ze zdolnościami do nauki języków obcych w rozumieniu kognitywnych predyspozycji językowych (Sobańska-Jędrych, 2010: 82-83).

\section{Samoocena ucznia uzdolnionego językowo jako czynnik warunkujący osiągnięcia w nauce języka obcego}

Ocena własnych uzdolnień, umiejętności i możliwości, jak podaje Pawlak (2011: 32), ma znaczny wpływ na osiągnięcie sukcesu w nauce języków obcych, w tym na osiągnięcia uczniów uzdolnionych językowo. Sama jednak nie jest cechą stałą i wrodzoną, co oznacza, że jest kształtowalna i zmienia się pod wpływem działania różnorodnych czynników (jak choćby środowisko) i jako taka nie jest częścią struktury zdolności językowych.

Zdefiniowanie pojęcia samooceny przysparza wielu problemów, często prowadząc do nieścisłości w jej rozumieniu. W literaturze przedmiotu jest definiowana jako wartość, jaką przypisujemy sobie samym (Fontana, 1998: 283), i utożsamiana również z pojęciem obrazu samego siebie czy też obrazu własnej osoby (Holling i Kanning, 1999: 60; Fleiß, 2003: 14). W podobny sposób definiuje ją Szewczuk (1985: 275), jako postawę wobec samego siebie, wobec własnych możliwości. W ujęciu stricte psychologicznym samoocena jest rozumiana jako „uogólniona, względnie trwała ocena siebie jako osoby” (Strelau, 2000: 573) i dotyczy oceny własnej różnych obszarów działalności człowieka. 
Zawadzka (2004: 244), odnosząc to pojęcie do kontekstu uczenia się i nauczania, wskazuje, że samoocena jest ważną cechą osobowości, która dotyczy rozbieżności między rzeczywistym obrazem własnej osoby a obrazem idealnym. Jednak może być również rozumiana jako umiejętność oceny postępu w rozwijaniu własnych kompetencji i umiejętności oraz efektywności uczenia się.

Samoocena jako czynnik afektywny zakłada udział czynnika środowiskowego oraz osobowościowego w jej kształtowaniu. To, jak człowiek sam się ocenia, ma wpływ na własne zachowanie i funkcjonowanie w społeczeństwie. Dzięki dobremu poznaniu swoich słabych i mocnych stron łatwiej jest pogodzić się z krytyką, przyznać się do popełnionego błędu, ale również lepiej wykorzystać swoje potencjalne zdolności (Niebrzydowski, 1997: 13). Osoby, które pozytywnie odnoszą się do własnych możliwości i osiągnięć, są również bardziej pewne siebie i bardziej zdecydowane w swoich decyzjach i działaniach. Zdecydowanie lepiej znoszą różnego rodzaju niepowodzenia, a także dużo chętniej podejmują wyzwania, jak również charakteryzują się wyższą motywacją do działania (Sobańska-Jędrych, 2010: 43).

Proces budowania wysokiej samooceny, szczególnie u uczniów zdolnych, jest złożony, a wpływ na niego ma wiele czynników, zarówno zewnętrznych (jak środowisko rodzinne i warunki w nim istniejące, środowisko rówieśnicze i szkolne), jak i wewnętrznych ucznia zdolnego, odnoszących się do jego cech osobowościowych. Współdziałanie wszystkich elementów tworzy obraz własny ucznia zdolnego: zarówno pozytywny, jak i negatywny. Jak zauważa Niebrzydowski (1997: 13-14), pierwsza ocena samego siebie powstaje dzięki kontaktom społecznym, które dostarczają nam wielu informacji o nas samych. $Z$ drugiej strony środowisko działa stymulująco na poziom samooceny, której wysoki poziom jest warunkiem motywacji wewnętrznej do działania, realizowania własnego potencjału twórczego i intelektualnego. Pozostaje jednak pytanie, czy, a jeśli tak, to w jakim zakresie, wysoka samoocena jest charakterystyczna dla uczniów uzdolnionych (Sobańska-Jędrych, 2010: 44)?

Badania samooceny uczniów zdolnych pozwalają określić, jak postrzegają oni samych siebie, a w szczególności, jak postrzegają swoje zdolności (Marburger Hochbegabtenprojekt za: Flei $\beta, 2003$ ). Wyniki pokazują, że uczniowie zdolni przeważnie za takich się uważają, choć wśród nich są również i tacy, którzy, choć zostali zdiagnozowani jako uzdolnieni, za takich się nie mają. Przeważnie pozytywnie odnoszą się do swoich zdolności, w których upatrują dużą szansę rozwoju osobistego, zwracają uwagę na to, że dzięki nim lepiej funkcjonują na płaszczyźnie kognitywnej: łatwiej się uczą, szybciej pojmują i łatwiej rozwiązują problemy. Jednak zostaje ukazana również druga strona zdolności, odnosząca się przeważnie do aspektów społecznych. Uczniowie dostrzegają stereotypy wiążące się ze zdolnościami, polegające na negatywnym 
postrzeganiu ich przez innych uczniów, wskazują na poczucie wyizolowania i niezrozumienia ze strony rówieśników. Towarzyszy im nawet poczucie wykorzystywania przez innych ze względu na swój duży potencjał intelektualny (Holling i Kanning, 1999: 61; Fleiß, 2003: 15).

Powyższe wyniki badań jasno wskazują na zależność między poziomem samooceny a funkcjonowaniem uczniów uzdolnionych oraz ich osiągnięciami. Można zatem przyjąć, że ta sfera uczniów uzdolnionych jest istotnym elementem w procesie nauczania/uczenia się języków obcych. Poznanie jej przez nauczyciela pozwala zarówno ją kształtować jako osobny obszar różnic indywidualnych, jak również efektywnie planować i realizować działania wspierające ucznia uzdolnionego w szkole.

\section{Metodologia badań własnych}

Punktem wyjścia dla wspomnianych wyżej działań wspierających uczniów uzdolnionych na lekcji, w tym uczniów wykazujących ponadprzeciętne uzdolnienia w nauce języków obcych, jest nie tylko poznanie struktury samych zdolności językowych, ale również specyfiki funkcjonowania uczniów uzdolnionych w szkole. Problematyka oceny własnych uzdolnień uczniów stanowiła przedmiot badań autorki artykułu w zakresie identyfikacji i rozwijania zdolności na lekcji języka obcego $^{2}$. Zasadne bowiem staje się pytanie, jak uczniowie uzdolnieni językowo postrzegają siebie w kontekście swoich specjalnych uzdolnień? W związku z tym w badaniu podjęta została próba odpowiedzi na następujące pytania:

1) Czy uczniowie uznani za uzdolnionych językowo faktycznie za takich się postrzegają?

2) Jak uczniowie uznani za uzdolnionych językowo postrzegają swoje wyniki w nauce?

3) Jak uczniowie uznani za uzdolnionych językowo odnoszą się do swoich osiągnięć w zakresie języków obcych?

Badania zostały przeprowadzone w dziewięciu liceach ogólnokształcących z małych i średnich miast trzech różnych województw. Wzięło w nich udział 64 nauczycieli różnych języków obcych i 401 wytypowanych przez nich uczniów jako uzdolnionych językowo.

Sposobem doboru uczniów ze zdolnościami do nauki języków obcych były wskazania nauczycieli języków obcych według ich własnych kryteriów, do których należały cechy kognitywne, cechy pozakognitywne (aktywność na lekcji,

\footnotetext{
${ }^{2}$ Prezentowane wyniki stanowią część szerszych badań dotyczących identyfikowania i rozwijania zdolności językowych w szkole, stanowiących podstawę nieopublikowanej rozprawy doktorskiej autorki artykułu (Sobańska-Jędrych, 2010).
} 
zainteresowanie językiem, zaangażowanie, systematyczność i samodzielność w nauce, oryginalność myślenia, otwartość na nowość, pracowitość, umiejętność pracy w zespole, pewność siebie czy dokładność) oraz wyniki w nauce. Sposób wytypowania uczniów uzdolnionych językowo przez nauczycieli języków obcych oraz subiektywne kryteria identyfikacyjne zastosowane przez nauczycieli, niezależnie od trafności ich identyfikacji, wydają się szczególnie istotne ze względu na fakt, że w praktyce to właśnie nauczyciel języków obcych rozpoznaje uczniów uzdolnionych zgodnie z własnymi przyjętymi metodami i kryteriami oraz podejmuje działania dydaktyczne mające na celu rozwijać potencjał wytypowanych uczniów w tym zakresie.

Dla pozyskania danych w badaniu wykorzystano kwestionariusze skierowane zarówno do nauczycieli języków obcych (dotyczące m.in. liczby wytypowanych uczniów uzdolnionych językowo i metody oraz kryteriów identyfikacyjnych), jak również do wytypowanych uczniów. Badania były anonimowe.

\section{Wyniki badań}

Zebrane w kwestionariuszu skierowanym do uczniów dane pozwalają dokonać następującej charakterystyki wytypowanej grupy uczniów w zależności od postawionych pytań szczegółowych.

\subsection{Ocena własnych uzdolnień uczniów}

Uczniowie uznani przez swoich nauczycieli języków obcych jako uzdolnieni językowo zostali poproszeni o wyrażenie zdania o własnych zdolnościach. Pytania dotyczyły opinii o sobie jako o uczniu zdolnym oraz jako o uczniu posiadającym szczególne uzdolnienia językowe.

Spośród wszystkich uczniów biorących udział w badaniu 77\% określa siebie jako uczniów zdolnych, natomiast $5 \%$ jako uczniów, którzy nie posiadają zdolności. $18 \%$ nie ma zdania na ten temat. Biorąc pod uwagę ich opinię na temat swoich zdolności do nauki języków obcych, $46 \%$ uważa się za uczniów uzdolnionych językowo, 36\% nie potrafi tego stwierdzić, natomiast 18\% uważa się za niezdolnych językowo.

Spośród wszystkich uczniów, którzy twierdzą, że są zdolni, 54\% uznaje się również za zdolnych językowo, 35\% nie ma zdania na ten temat, $11 \%$ natomiast uważa, że zdolności, które posiadają, nie są zdolnościami językowymi. 3,5\% wszystkich uczniów nie uważa się ani za uczniów zdolnych, ani za uczniów uzdolnionych językowo. 


\subsection{Ocena własnych wyników w nauce języków obcych}

Spośród wszystkich uczniów biorących udział w badaniu 93\% twierdzi, że ich wyniki w nauce języków obcych są wysokie, przy czym wyniki 56\% uczniów są wysokie z wszystkich języków obcych, których uczą się w szkole. Natomiast $37 \%$ wykazuje zróżnicowanie pod tym względem. W tym przypadku wysokie wyniki badani uczniowie osiągają jedynie w nauce jednego języka obcego, natomiast w nauce innego języka bądź innych języków pozostają na poziomie przeciętnym lub niskim. 7\% uczniów wykazuje przeciętne bądź niskie wyniki w nauce wszystkich języków obcych, których uczą się w szkole.

Uwzględniając kryteria identyfikacyjne zastosowane przez nauczycieli języków obcych, można stwierdzić, że 61\% uczniów posiadających wysokie wyniki w nauce wszystkich języków obcych znajduje się w grupie uczniów wytypowanych wyłącznie według cech kognitywnych jako głównego kryterium identyfikacyjnego. Im bardziej podczas rozpoznawania uczniów brane są pod uwagę ich cechy pozakognitywne, jak sumienność, aktywność na lekcji, dobra organizacja pracy itd., tym mniej jest uczniów posiadających wysokie wyniki z wszystkich języków obcych.

Zgodnie z wynikami badań 59\% uczniów uważających się za uczniów ze zdolnościami do nauki języków obcych ma wysokie wyniki w nauce wszystkich języków obcych. Porównywalny wynik dotyczy również uczniów, którzy nie potrafią określić, czy są uczniami uzdolnionymi językowo (58\%). 41\% uczniów, którzy mają wysokie wyniki w nauce wszystkich języków obcych, to uczniowie, którzy twierdzą, że nie posiadają zdolności językowych. Zauważalna jest jednak różnica w liczbie uczniów posiadających niskie wyniki w nauce z wszystkich języków obcych. O ile w przypadku uczniów, którzy uważają się za uzdolnionych językowo, niskie wyniki w nauce języków obcych ma tylko jeden, o tyle w przypadku uczniów, którzy uważają siebie za nieuzdolnionych językowo, jest ich $25 \%$.

\subsection{Ocena własnych osiągnięć w nauce języków obcych}

Wyniki kwestionariusza skierowanego do badanych uczniów dotyczące osiągnięć w nauce języka obcego bądź języków obcych pokazują, że 268 (70\%) z nich jest zdania, że je posiada. Przeciwnego zdania jest 113 uczniów, tj. 30\%. Analiza odpowiedzi uczniów pozwoliła wyłonić następujące wskaźniki osiągnięć w nauce języków obcych. Są to:

- udział i wysokie wyniki w konkursach i olimpiadach językowych;

- swobodne porozumiewanie się w języku obcym (językach obcych), wysoko rozwinięta kompetencja językowa;

- $\quad$ wysokie oceny z języka obcego (języków obcych); 
- uzyskanie certyfikatu językowego;

- rozwinięcie zainteresowań związanych z językiem obcym.

Wśród uczniów, którzy udzielili odpowiedzi twierdzącej na temat osiągnięć językowych, wskaźniki te pojawiały się w różnych konstelacjach. $41 \%$ uczniów uważa za swoje szczególne osiągnięcia językowe swobodne i bezproblemowe porozumiewanie się w języku obcym. 22\% badanych uczniów uważa, że ich szczególnym osiągnięciem są wysokie miejsca w konkursach i olimpiadach językowych, dla $11 \%$ są to zarówno wysokie oceny z języków obcych, jak również swobodne porozumiewanie się w języku obcym. 9\% traktuje wyłącznie wysokie oceny jako swoje osiągnięcia, $6 \%$ - wysokie miejsca w konkursach i olimpiadach oraz swobodne porozumiewanie się w języku obcym, 7\% - oceny oraz wysokie miejsca w konkursach i olimpiadach językowych, 3\% - certyfikat językowy. Jeden uczeń uważa za swój sukces udział w projektach językowych w Internecie oraz rozwinięcie zainteresowań związanych z językiem obcym.

Wynik badania osiągnięć językowych uczniów koreluje dodatnio z opiniami uczniów o własnych zdolnościach językowych. Zgodnie z tym:

- $\quad 86 \%$ uczniów uważających się za uczniów uzdolnionych językowo twierdzi, że posiada osiągnięcia językowe;

- $66 \%$ uczniów, którzy nie potrafią ocenić swoich zdolności, twierdzi, że posiada osiągnięcia językowe;

- 37\% uczniów, którzy nie uważają się za uczniów uzdolnionych językowo, twierdzi, że posiada osiągnięcia językowe.

\section{Podsumowanie i wnioski}

Uzyskane dane pozwalają wnioskować, że uczniowie uznani przez swoich nauczycieli języków obcych za uzdolnionych językowo uważają się za uczniów bardziej zdolnych w innych dziedzinach. Tylko połowa z nich uważa, że posiada predyspozycje do nauki języków obcych, co trzeci uczeń nie potrafi tego stwierdzić, natomiast prawie co piąty nie uważa się za takiego ucznia. Wskazuje to na ogólny obraz uczniów uznanych za uzdolnionych językowo jako osób, które krytycznie oceniają własne uzdolnienia językowe. Choć z reguły pozytywnie oceniają swoje wyniki w nauce języków obcych, widoczni są wśród nich również tacy, którzy wysokie wyniki osiągają w nauce określonego języka, w innym natomiast ich wyniki są przeciętne bądź niskie. Dotyczy to połowy badanych uczniów. Jeśli chodzi o postrzeganie własnych osiągnięć, uczniowie zdolni raczej je dostrzegają. Niemniej w grupie badanych uczniów są również tacy, którzy negatywnie odbierają własne osiągnięcia. 
Przedstawiona w badaniach rozbieżność między postrzeganiem siebie jako osoby uzdolnionej a wykazującej uzdolnienia językowe jest niewątpliwie zastanawiająca. Problem oceny własnych uzdolnień wymaga zatem dalszych pogłębionych dociekań. Obecnie przedstawione nie wskazują bowiem źródeł takiego stanu rzeczy. Jako że prymarnym czynnikiem wpływającym na kształtowanie oceny własnej ucznia w różnych obszarach jego działalności jest szeroko rozumiane środowisko (rodzina, rówieśnicy, a przede wszystkim nauczyciel języków obcych), istotnym obszarem badań w tym zakresie byłyby działania nauczyciela, ich zakres oraz wpływ na kształtowanie samooceny uczniów uzdolnionych językowo. Pytanie takie zdaje się być ważkie z perspektywy działań wspierających rozwój zdolności językowych u uczniów.

Reasumując, można stwierdzić, że same uzdolnienia do nauki języków obcych w rozumieniu czynników kognitywnych ani nie wpływają na wysokie i adekwatne przekonanie o własnych zdolnościach oraz możliwościach uczniów, ani nie gwarantują sukcesu w nauce języków obcych, choć z pewnością pozostają w zależnościach między sobą.

\section{BIBLIOGRAFIA}

Biedroń, A. 2012: „Profil poznawczo-osobowościowy ponadprzeciętnie uzdolnionych uczniów języka obcego". (w) Nauczanie języka obcego a specyficzne potrzeby uczqcych się. O kompetencjach, motywowaniu i strategiach. (red. J. Knieja i S. Piotrowski). Lublin: Towarzystwo Naukowe Katolickiego Uniwersytetu Lubelskiego, str. 77-91.

Carroll, J. B. 1993. Human cognitive abilities: a survey of factor-analytic studies. Cambridge: Cambridge University Press.

Carroll, J. B. i S. M. Sapon. 2002 [1959]. Modern Language Aptitude Test. Bethesda, MD: Second Language Testing.

Costa, P. T. i R. R. McCrae. 1992. „Four ways Five Factors are basic“. Personality and Individual Differences, 13: 653-665.

Esser, U. 1982. „Ein allgemeinpsychologischer Ansatz zur Diagnose der Fremdsprachenlernbefähigung". Deutsch als Fremdsprache, 2: 76-81.

Flei $\beta$, I. 2003. Hochbegabung und Hochbegabte. Marburg: Tectum Verlag.

Fontana, D. 1998. Psychologia dla nauczycieli. Poznań: Wydawnictwo Zysk i S-ka.

Grigorenko, E. L., R. J. Sternberg i M. E. Ehrman. 2000. „A theory-based approach to the measurement of foreign language learning ability: The CANAL - F theory and test". Modern Language Journal, 84(3): 390-405.

Holling, H. i U. P. Kanning. 1999. Hochbegabung. Forschungsergebnisse und Fördermöglichkeiten. Göttingen: Hogrefe.

Morgan, W. J. 1953. „A Clinical Approach to Foreign Language Achievment“. Monograph Series on Languages and Linguistics, 4: 20. 
Niebrzydowski, L. 1997: „Czynniki warunkujące proces samorealizacji młodzieży dorastającej". (w) Drogi samorealizacji młodzieży dorastajqcej. (red. L. Niebrzydowski). Łódź: Wydawnictwo Uniwersytetu Łódzkiego, str. 7-17.

Pawlak, M. 2011. „Nowe spojrzenie na dobrego ucznia w dydaktyce językowej”. Języki Obce w Szkole, 1: 28-36.

Pimsleur, P., R. Stochwell i A. Comrey. 1962. „Foreign Language Learning Ability”. Journal for Education and Psychology, 53: 15-26.

Rysiewicz, J. 2010. „Krytyczna analiza dwóch narzędzi do pomiaru uzdolnień do nauki języków obcych". Studia Psychologiczne, 48(3): 49-60.

Sang, F. i H. J. Vollmer. 1978. Allgemeine Sprachfähigkeit und Fremdsprachenerwerb. Berlin: Max-Planck-Institut für Bildungsforschung.

Schütt, H. 1974. Fremdsprachenbegabung und Fremdsprachenleistung. Frankfurt: Diesterweg.

Sękowski, A. E. i O. Bilyakovska. 2011. „Zdolności człowieka jako wymiar psychologiczny”. Języki Obce w Szkole, 1: 18-24.

Sękowski, A. E. i M. Rudź. 2011. „Charakterystyka osobowości i stylów poznawczych osób uzdolnionych językowo". Języki Obce w Szkole, 1: 37-42.

Skehan, P. 1998. A cognitive approach to language learning. Oxford: Oxford University Press.

Snow, R. E. 1994: „Abilities in academic tasks”. (w) Mind in Context: Interactionist Perspectives on Human Intelligence. (red. R. J. Sternberg i R. K. Wagner). Cambridge, NJ: Cambridge University Press, str. 3-37.

Sobańska-Jędrych, J. 2010. Uczeń zdolny - uczenie się i nauczanie języków obcych. Nieopublikowana praca doktorska. Warszawa: Uniwersytet Warszawski.

Strelau, J. 1997. Inteligencja człowieka. Warszawa: Wydawnictwo Edukacyjne Żak.

Strelau, J. 2000. Psychologia. Podręcznik akademicki. Gdańsk: GWP.

Szewczuk, W. 1985. Słownik psychologiczny. Warszawa: Wiedza Powszechna.

Wesche, M. B., H. Edwards i W. Welss. 1982. „Foreign language aptitude and intelligence". Applied Psycholinguistics, 3(1): 127-140.

Zawadzka, E. 2004. Nauczyciele języków obcych w dobie przemian. Kraków: Impuls. 